\title{
Pengembangan Buku Teks Matematika Berbasis Investigasi untuk Meningkatkan Penalaran Aljabar
}

\author{
Mochamad Abdul Basir ${ }^{1 *}$, Mohamad Aminudin ${ }^{2}$ \\ 1,2 Universitas Islam Sultan Agung Semarang \\ *abdulbasir@unissula.ac.id
}

Diterima: Nopember 2019. Disetujui: Desember 2019. Dipublikasikan: Januari 2020.

\begin{abstract}
ABSTRAK
Aljabar merupakan generalisasi aritmatika sehingga dijadikan sebagai titik awal pembelajaran matematika tingkat lanjut. Meski aljabar sangat penting namun siswa memiliki banyak kendala dalam mempelajari aljabar. penelitian pengembangan ini bertujuan untuk mengembangkan buku teks matematika berbasis investigasi dalam meningkatkan kemampuan penalaran aljabar siswa. Tujuan dari buku teks matematika adalah untuk memfasilitasi siswa menyelidiki masalah dalam materi Persamaan Kuadrat. Penelitian pengembangan menggunakan model Four-D yang dimodifikasi diantaranya Define (identifikasi dan pengembangan struktur model bahan ajar), Desain (desain buku teks untuk mendapatkan prototipe yang sesuai dengan pembelajaran yang akan dilakukan), Develop (Pengembangan draft buku teks berdasarkan ahli diperoleh dari uji coba lapangan). Untuk tahap DIseminate pada tahap ini tidak dilakukan. Pada setiap tahappengembangan berisi kegiatan yang menunjukkan adanya urutan langkah-langkah kegiatan. Khususnya, dalam tahap Develop berisi siklus kegiatan. Prosedur penelitian ini dimulai dengan tahap awal studi mendalam tentang eksplorasi kebutuhan buku teks yang dilakukan sebagai cara mengatasi kesalahpahaman siswa dalam menyelesaikan masalah persamaan kuadrat melalui investigasi untuk meningkatkan penalaran aljabar. Langkah selanjutnya adalah menyusun buku teks matematika berbasis investigasi. Buku teks yang dihasilkan divalidasi oleh para ahli dalam pendidikan matematika dan para ahli dalam buku teks matematika. Buku teks diuji secara terbatas untuk mengetahui kepraktisan buku teks. Alhasil dalam penelitian ini diperoleh buku teks matematika berbasis investigasi yang valid dan praktis.

Kata kunci: analisis, struktur kognitif, berpikir matematis, bilangan bulat.
\end{abstract}

\section{ABSTRACT}

The algebraic concept is a generalization of arithmetic so that it is used as an entry point in further learning mathematics. Thus algebra is important. However students have many obstacles in learning algebra. This is development research to develop mathematics textbooks to improve students' algebraic reasoning abilities. The purpose of mathematics textbooks is to facilitate students investigate problems in the material of Quadratic Equations. This development study used a modified Four-D model include Define (identification and development of instructional material model structures), Design (textbook design to obtain prototypes that are appropriate to the learning to be carried out), Develop (Improved draft textbooks based on expert input and data obtained from field trials). At each stage contains activities that indicate the existence of a sequence of steps of activity. Especifically, in the Develop stage contains the activity cycle. The procedure of this study begin with the early stages an in-depth study of the exploration of the needs of textbooks was carried out as a means of overcoming students' misconceptions in solving investigative quadratic equation problems to improve algebraic reasoning abilities. The next step is to compile a textbook that is presented in print media. The resulting textbooks were validated by experts in mathematics education and experts in mathematics textbook. After that the textbook tested in a limited way through developmental experimental studies to study the practicality of textbooks. As a result this study can obtain a valid and practical textbook has obtained.

Keywords: algebraic reasoning, investigation, mathematics textbooks.

How to Cite: Basir, M. A. \& Aminudin, M. (2020). Pengembangan Buku Teks Matematika Berbasis Investigasi untuk Meningkatkan Penalaran Aljabar. Journal of Medives: Journal of Mathematics Education IKIP Veteran Semarang, 4(1), 53-62. 


\section{PENDAHULUAN}

Matematika merupakan ilmu tentang pola dan urutan. Sebagai ilmu dengan objek yang abstrak, matematika bergantung pada logika. Standar kebenaran matematika bukan pada pengamatan, meskipun menggunakan pengamatan, simulasi dan bahkan percobaan sebagai alat untuk menemukan kebenaran (Walle, 2007). Untuk itu, dalam mengajarkan matematika secara efektif, diperlukan pemahaman tentang apa yang siswa ketahui dan perlukan untuk belajar kemudian memberikan tantangan dan mendukung siswa untuk mempelajarinya dengan baik (NCTM, 2000). Hampir keseluruhan apa yang dipelajari siswa tergantung pada pengalaman guru dalam mengajar di kelas. Sehingga guru harus memahami materi matematika yang diajarkan secara mendalam, memahami bagaimana siswa belajar matematika termasuk di dalamnya mengetahui perkembangan matematika secara individual, serta guru cakap dalam memilih tugas dan strategi pembelajaran matematika sedemikian hingga diperoleh peningkatan mutu proses pembelajaran.

Pembelajaran yang ideal sesuai dengan yang diamanatkan Kendikbud (2012), yaitu Pembelajaran yang diarahkan untuk mendorong siswa mencari tahu dari berbagai sumber dan bukan hanya diberi tahu; Pembelajaran yang diarahkan untuk mampu merumuskan masalah masalah (menanya), bukan hanya untuk menyelesaikan masalah atau menjawab; Pembelajaran yang diarahkan untuk melatih berpikir analitis (pengambilan keputusan) bukan berpikir mekanis atau rutin; Pembelajaran yang menekankan pentingnya kerjasama dan kolaborasi dalam menyelesaikan masalah. Beberapa cara yang dapat digunakan untuk mengaktifkan siswa agar mereka berpikir dan bernalar adalah dengan memberikan soal yang mengarah pada jawaban konvergen, divergen, atau penyelidikan.

Pembelajaran matematika tidak hanya memerlukan keterampilan berhitung akan tetapi juga memerlukan kecakapan untuk berpikir dan berargumen secara matematis untuk menyelesaikan masalah baru dan mempelajari ide-ide baru. Untuk itu, pembelajaran matematika di dalam kelas perlu ditingkatkan melalui eksplorasi siswa untuk menilai ide siswa lain, didorong untuk membuat dugaan tentang matematika kemudian mengujinya dan dikembangkan keterampilan dalam memberikan alasan yang logis. Sehingga dalam hal ini guru mempunyai peranan dalam memberikan semangat kepada siswa untuk melakukan penyelidikan, memberikan kepercayaan, dan memberikan kesempatan. Evans berpendapat bahwa pengajaran matematika harus melibatkan aktivitas-aktivitas di antaranya; eksposisi, diskusi, kerja praktis, konsolidasi, pemecaham masalah, and investigasi (Yeo, 2009). Problem solving merupakan convergent activity di mana siswa harus belajar mencari penyelesaian yang sudah jelas arahnya, sedangkan investigation adalah divergent activity dimana siswa lebih diberikan kesempatan untuk memikirkan, mengembangkan, dan menyelidiki hal-hal menarik yang mengusik rasa keingintahuan siswa. Investigating is not just getting the right answer but asking the right questions. 
Kegiatan penyelidikan dapat melatih siswa tidak hanya menerima sesuatu yang sudah instan kemudian digunakan begitu saja, namun siswa dilatih agar dapat menggunakan keterampilannya untuk berpikir dan bernalar. Sehingga dapat memberi kesempatan pada siswa untuk berpikir tentang situasi kuantitaif secara umum dan relasional, dalam hal ini disebut algebraic reasoning. Pemikiran semacam ini dioptimalkan oleh pemahaman yang cukup besar tentang objek-objek aljabar, disposisi untuk berpikir secara umum, dan keterlibatan dalam tugastugas tingkat tinggi yang menyediakan konteks untuk menerapkan dan menyelidiki matematika dan dunia nyata.

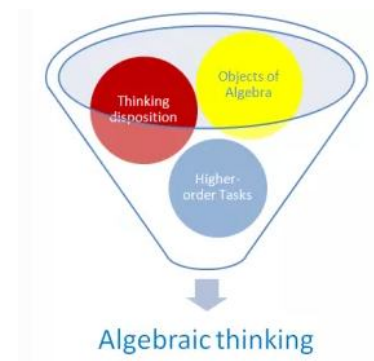

Gambar 1. Algebraic Thinking

Kaput menyarankan bahwa domain aljabar terdiri dari praktik pemikiran tertentu dan untaian konten. Secara khusus, pemikiran aljabar termasuk membuat dan mengkomunikasikan generaslisasi dalam sistem simbol yang semakin formal dan konvensional dan penalaran dengan bentuk simbolik (Kaput, 2008). Penekanan dalam pembelajaran aljabar, tidak terletak pada aktivitas qualified secara aljabar, namun lebih menekankan pada proses berpikir dan penalaran (Yachel, 1997). Dike- mukakan oleh Kaput \& Blankton (2005) algebraic reasoning is a process in which students generalize mathematical ideas from a set of particular instances, establish those generalizations through the discourse of argumentation, and express them in increasingly formal and age-appropriate ways.

Berdasarkan framework yang dikemukakan oleh Driscoll (2003), terdapat tiga habit dalam meningkatkan penalaran aljabar; doing/undoing (mencari input dari output atau mencari nilai awal dari sebuah solusi serta working backward), abstracting from computation (melihat cara hitung cepat berdasarkan pemahaman tentang bagiamana operasi bekerja, berpikir tentang perhitungan secara independen terhadap bilangan yang digunakan, melampaui beberapa contoh untuk membuat ekspresi generalisasi dan mendeskripsikan sekumpulan bilangan atau menyatakan konjektur dari suatu kondisi dimana pernyataan matematis tertentu bernilai benar, mempertimbangkan ekuivalensi diantara berbagai ekspresi), building rules to represent functions (mengorganisasi informasi yang berguna untuk mengungkap pola dan aturan yang mendefinisikan pola, mencatat aturan yang dapat digunakan dan memprediksi bagaimana aturan tersebut bekerja).

Salah satu tugas guru adalah mendorong siswa untuk berpikir, bertanya, memecahkan masalah, serta mendiskusikan ide-ide, strategi, dan penyelesaian agar kemampuan penalaran aljabar siswa meningkat. Dalam membelajarkan matematika, guru seharusnya memperhatikan kebermaknaan dengan mengoptimalkan pengetahuan yang 


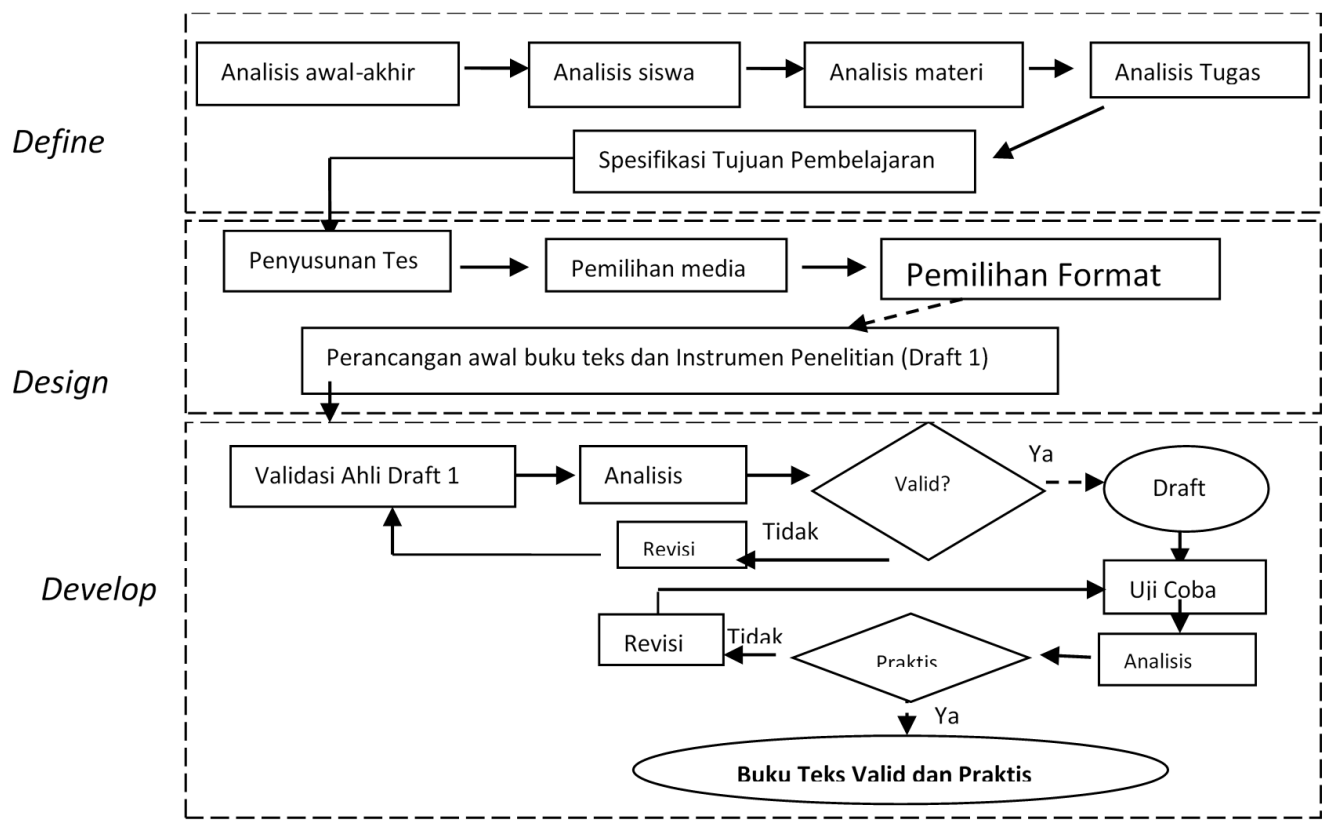

Gambar 2. Modifikasi Model Pengembangan Four-D

dimiliki siswa, kerjasama dalam berkelompok dan adanya kolaborasi antara guru dengan siswa. Guru tidak sekedar memberikan pengetahuan kepada siswa, akan tetapi guru sebaiknya memfasilitasi siswa dan memberikan scaffolding untuk membangun pengetahuan siswa sendiri sehingga membawa siswa pada pemahaman yang lebih tinggi. Basir (2015) berpendapat bahwa selama tahap awal pembelajaran, siswa memerlukan scaffolding yang merupakan pemberian sejumlah bantuan kepada siswa kemudian mengurangi bantuan tersebut secara perlahan untuk memberikan kesempatan pada siswa mengambil alih tanggung jawab yang semakin besar setelah siswa dapat melakukannya. Bantuan tersebut dapat berupa petunjuk, dorongan, peringatan, menguraikan masalah ke dalam langkah-langkah pemecahan masalah, memberikan contoh, dan tindakan-tindakan lain yang memungkinkan siswa dapat belajar mandiri. Dengan demikian siswa dapat belajar matematika melalui pemahaman, siswa secara aktif membangun pengetahuan baru dari pengalaman dan pengetahuan sebelumnya melalui investigasi.

Dengan demikian permasalahan yang dirumuskan adalah bagaimana pengembangan buku teks matematika berbasis investigasi dalam meningkatkan kemampuan penalaran aljabar?

\section{METODE PENELITIAN}

Penelitian pengembangan buku teks matematika berbasis investigasi termasuk jenis penelitian Research and Development model Four-D modifikasi dari model Thiagarajan, Semmel, and Semmel (1974) yaitu pendefinisian (Define), Perancangan (Design), dan Pengembangan (Develop).

Tahap define bertujuan untuk menetapkan dan mendefinisikan syaratsyarat yang diperlukan dalam pembelajaran. Tahap design bertujuan untuk 
merancang buku teks sehingga diperoleh prototype yang sesuai. Sedangkan tahap develop menghasilkan draft yang sudah direvisi berdasarkan masukan para ahli dan data yang diperoleh dari lapangan. Buku teks yang dikembangkan berbasis investigasi untuk meningkatkan penalaran aljabar siswa. Instrumen penelitian yang dikembangkan berupa lembar validasi buku teks, angket respon siswa dan angket guru.

Metode pengumpulan data kevalidan buku teks dengan cara mengumpulkan penilaian dari validator, data kepraktisan buku teks dengan cara pemberian angket respon guru dan respon siswa. Serta data kemampuan penalaran aljabar siswa diperoleh dari lembar tes. Teknik analisis data pada draft buku teks diberikan penilaian oleh validator, sesuai dengan rubrik yang dibuat peneliti.

Data yang tertera pada lembar validasi merupakan penilaian masingmasing validator terhadap buku teks. Kepraktisan penggunaan buku teks ditinjau dari respon guru dan siswa. Kerangka desain penelitian pengembangan disajikan pada Gambar 2.

\section{HASIL DAN PEMBAHASAN}

Salah satu kriteria utama untuk menentukan dipakai tidaknya suatu buku teks adalah hasil validasi oleh ahli. Penilaian validasi oleh ahli meliputi validasi isi, yaitu mencakup buku teks yang dikembangkan pada tahap perancangan. Hasil penilaian kelima validasi ahli terhadap buku teks matematika berbasis investigasi untuk meningkatkan kemampuan penalaran aljabar sebagai berikut 4,22; 4,31; 4,27;
4,23; dan 4,41 sehingga diperoleh ratarata penilaian 4,29 dari skor maksimal 5,00. Dengan demikian hasil penilaian validator terhadap buku teks matematika berbasis investigasi untuk meningkatkan kemampuan penalaran aljabar berkategori sangat baik.

Buku teks matematika yang telah direvisi sesuai dengan saran validator, selanjutnya diujicobakan pada kelas kecil untuk memperoleh masukanmasukan guna menyempurnakan kembali buku teks. Selama proses uji coba, dilakukan pengambilan data meliputi data angket respon siswa dan guru. Hasil angket respon siswa diperoleh 92,5\% siswa senang terhadap buku teks, 93,25\% siswa berpendapat buku teks matematika berbasis investigasi adalah hal yang baru, 92\% siswa berminat mengikuti kegiatan pembelajaran menggunakan buku teks matematika berbasis investigasi, 91,5\% siswa memahami keterbacaan buku teks dan 90,75\% siswa tertarik terhadap penampilan buku teks. Data yang ditunjukkan dari respon guru diperoleh hasil sebagai berikut: penilaian guru terhadap buku teks menunjukkan hasil yang baik; ketertarikan guru terhadap pemakaian buku teks menunjukkan hasil ingin memakai bahan ajar; pendapat guru terhadap buku teks kaitannya dengan tugas mengajar menunjukkan hasil bahwa buku teks sangat membantu.

Pengembangan buku teks matematika berbasis investigasi melalui tahapan define, design, dan develop. Pada tahap define, terdapat masalah mendasar di mana siswa cenderung pasif dalam kemonotonan pembelajaran di kelas yang bersifat satu arah saja sehingga 
kemampuan penalaran belum diberdayakan secara optimal. Hal ini mengakibatkan siswa tidak terbiasa menyelesaikan soal non rutin yang merupakan soal tantangan dalam penyelesaian masalah. Adanya buku teks yang tersedia belum bisa dijadikan solusi karena hanya terdapat ringkasan materi, contoh soal dan soal latihan yang belum memfasilitasi tahapan siswa melakukan penalaran.

Kompetensi dasar matematika yang disusun dalam pengembangan buku teks matematika, yaitu merancang dan mengajukan masalah nyata terkait persamaan kuadrat, digunakan sebagai landasan pembelajaran untuk mengolah, menalar, dan menyaji dalam ranah konkret dan ranah abstrak terkait dengan pengembangan dari yang dipelajarinya di sekolah secara mandiri, bertindak secara efektif dan kreatif, serta mampu menggunakan metode sesuai kaidah keilmuan.

Pada tahap design, bahan ajar yang digunakan adalah buku teks yang dilengkapi lembar kegiatan siswa pada materi persamaan kuadrat yang membahas tentang akar-akar persamaan kuadrat dalam pemecahan masalah. Hal ini dikarenakan media lembar kegiatan siswa dapat memudahkan siswa menganalisis, mencari informasi, memecahkan masalah, dan menarik kesimpulan tentang persamaan kuadrat. Pemilihan format pengembangan buku teks matematika berbasis investigasi; (1) menemukan/mencari suatu permasalahan yang menarik dan bermanfaat; (2) membahas secara informal dan acak untuk menghasilkan suatu data; (3) membuat pola/model dari data-data yang sudah terkumpul sebagai dasar menyusun hipotesis; (4) menggunakan berbagai cara dan strategi pemecahan masalah yang mungkin untuk membuktikan kebenaran tersebut; (5) mengaplikasikan kemampuan dasar yang siswa miliki dalam proses pembuktian; (6) mengembangkan dan menggeneralisasikan sekaligus mengelompokkan hasil yang didapat; (7) mempublikasikan penemuan tersebut; dan (8) kembali ke langkah pertama. Rancangan awal ini merupakan rancangan draft pertama yang masih berupa prototype yang selanjutnya akan divalidasi oleh ahli.

Pada tahap develop, prototype buku teks matematika diberikan penilaian validasi oleh ahli meliputi validasi isi. Nilai rata-rata yang diberikan oleh para validator adalah 4,29 yang berarti buku teks valid dan dapat digunakan dengan sedikit revisi. Pada umumnya saransaran yang diberikan validator sebagai berikut: tampilan buku teks perlu ditambahkan penciri dari buku teks lainnya, penyajian materi kurang mendalam, dan lambang-lambang matematika ditulis dalam mathematics equation, serta font dibuat secara konsisten besarnya. Hasil revisi berdasarkan penilaian validator menghasilkan draft II. Karakteristik buku teks matematika berbasis investigasi yang telah dirancang sebagai berikut.

1. Cover dari buku teks matematika diberi judul “Buku Teks Matematika”, Agar buku teks ini menjadi penciri dari buku teks matematika lainnya, maka pada cover dituliskan identitas "Berbasis Investigasi" berikut contoh dari cover buku teks. 


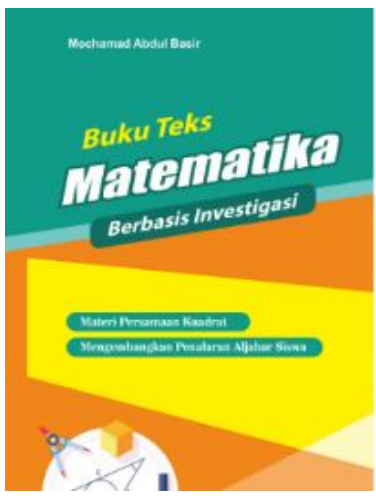

Gambar 3. Cover Buku Text

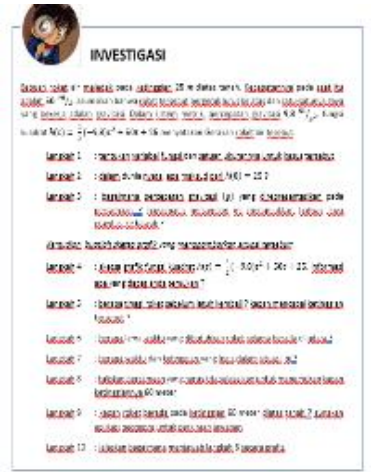

Gambar 5. Pembelajaran Matematika Berbasis Investigasi

4. Bantuan lembar kegiatan siswa dirancang sedemikian hingga memudahkan siswa dalam penyelesaian masalah melalui tahapan investigasi. Berikut contoh desainnya.

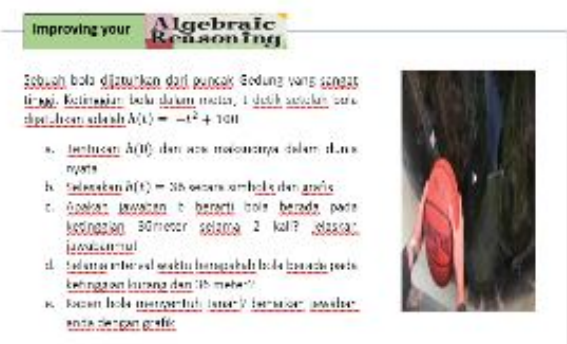

Gambar 6. Lembar Pengerjaan Soal

Pada tahap develop, setelah diperoleh prototype dalam bentuk draft kedua hasil revisi sesuai yang disarankan ahli buku teks matematika berbasis investigasi diujicobakan dalam kelas terbatas. Hal ini bertujuan untuk melihat kelemahan dan kepraktisan buku teks. Kelemahan dalam penggunaan buku teks yang diperoleh sebagai bahan masukan untuk melakukan revisi terhadap draft II. Hasil angket respon siswa menunjukkan bahwa persentase terbesar terdapat pada respon siswa terhadap keterbaruan buku teks matematika berbasis investigasi 
sebanyak 93,25\%. Melalui tahapan investigasi dalam penyelesaian masalah matematika yang terdapat pada buku teks, menjadikan siswa memperoleh kesimpulan dari yang sudah dipelajari berdasarkan data yang dilihat dan dianalisis sendiri. Hal ini tidak hanya membuat siswa lebih mengerti materi yang dipelajari, akan tetapi juga membiasakan berpikir dalam urutan yang terurut dan logis. Pada saat siswa mempresentasikan hasil pekerjaannya, tahapan investigasi memfaslitasi model komunikasi antara guru dan siswa. Melalui pertanyaan-pertanyaan khusus, siswa dapat dibantu untuk menguji prosedur yang telah dilakukan. Pertanyaan yang dapat ditanyakan oleh guru antara lain (1) adakah cara lain yang dapat kamu gunakan untuk menyelesaikan masalah ini? (2) apakah ini satusatunya cara yang diketahui untuk menyelesaikan tugas ini? (3) dapatkah ditemukan cara yang tercepat dalam menyelesaikan tugas ini? (4) apakah dicatat semua langkah-langkah yang sudah dilakukan untuk menyelesaikan masalah ini? (5) apakah prosedur yang dikerjakan sudah jelas? (6) bisakah orang lain mengerti cara-cara mengerjakannya? Dengan demikian, siswa ikut memikirkan secara informal tentang fakta-fakta yang ada, kemudian semua fakta ini dikumpulkan dan disusun menjadi suatu susunan data. Dari data yang tersedia, siswa membuat hipotesis atau teori dan dibuktikan kebenaran teori tersebut.

Implikasi penggunaan buku teks matematika berbasis investigasi terhadap kemampuan penalaran aljabar siswa sebagai berikut penalaran matematika merupakan komponen penting dari belajar matematika dan merupakan alat untuk memahami abstraksi sebagaimana yang disampaikan Russel (1999). Ditambahkan oleh Jones (1999) dan NCTM (2000) bahwa penalaran matematika dapat dijadikan pondasi dalam memahami dan doing matematika. Sedangkan Artzt \& Yaloz (1999) menjelaskan bahwa penalaran matematika merupakan bagian integral dari pemecahan masalah (problem solving). Jika dikaitkan dengan berpikir (thinking), maka penalaran matematika merupakan komponen utama dari berpikir yang melibatkan pembentukan generalisasi dan menggambarkan konklusi yang valid tentang ide dan bagaimana ide-ide itu dikaitkan (Artzt \& Yaloz, 1999; Peressini \& Webb, 1999). Bernalar matematika dapat juga dipandang sebagai aktivitas dinamis yang melibatkan suatu variasi cara berpikir dalam memahami ide, merumuskan ide, menemukan relasi antara ide-ide, menggambarkan konklusi tentang ide-ide dan relasi antara ide-ide (Jones, 1999).

Dengan demikian jika ingin menyiapkan siswa untuk tangguh menghadapi masa depan, maka perlu dipersiapkan dan difaslitasi agar mampu membangun kebiasaan berpikir sehingga terbiasa menghadapi permasalahan dengan mudah melalaui pembelajaran berbasis investigasi. Tingkat kemampuan siswa menghadapi masalah akan bergantung pada kemampuan dan kebiasaan mereka dalam berpikir pada saat mengolah informasi maupun permasalahan yang dihadapi. Melalui tahapan investigasi, kegiatan yang diharapkan dapat mengasah kebiasaan 
berpikir siswa antara lain sebagai berikut.

1. Siswa berpikir dalam menemukan pola-pola atau model dari kejadian atau fakta-fakta yang ada. Dalam berbagai konteks matematika, siswa mampu menemukan pola-pola tersembunyi yang terdapat dalam data.

2. Siswa berpikir bagaimana melakukan suatu eksperimen. Ide-ide sederhana seperti mencatat hasilhasil perhitungan, mencoba mengoperasikan bilangan yang sangat kecil atau sangat besar, atau mengubah parameter suatu pengerjaan hitungan juga dapat membantu siswa bereksperimen.

3. Siswa berpikir bagaimana mendeskripsikan sesuatu.

4. Siswa berpikir dalam memperbaiki atau mengotak-atik suatu permasalahan dari berbagai aspek dan sudut pandang.

5. Siswa berpikir sebagai inovator.

\section{PENUTUP}

Berdasarkan proses pengembangan buku teks matematika berbasis investigasi yang telah dilakukan maka dapat disimpulkan bahwa pengembangan buku teks matematika dihasilkan melalui tiga tahapan, define, design, dan develop. Pada tahap develop, pengembangan buku teks telah melalui proses validasi dan dinyatakan memenuhi validasi isi dan konstruk yang ditetapkan oleh para ahli, dan dapat dinyatakan bahwa buku teks matematika berbasis investigasi untuk mengembangkan kemampuan penalaran aljabar tergolong valid serta respon positif siswa sebesar $92 \%$ siswa berminat mengikuti pembela- jaran menggunakan buku teks matematika berbasis investigasi selanjutnya. Guru juga memberikan respon yang positif dengan memberikan komentar sangat baik pada buku teks matematika yang disusun sehingga dapat disimpulkan buku teks matematika berbasis investigasi praktis penggunaannya

Saran untuk penelitian selanjutnya adalah sebaiknya dilakukan pengembangan buku teks matematika pada materi lainnya dan perlu dilakukan peneltian lanjutan untuk mengetahui keefektifan pembelajaran berbantuan buku teks matematika berbasis investigasi untuk meningkatkan kemampuan penalaran aljabar siswa.

\section{DAFTAR PUSTAKA}

Artzt \& Yalloz. (1999). Mathematical Reasoning during Small-Group Problem Solving in Lee V. Stiff dan Frances R. Curcio (edt) Developing Mathematical Reasoning in Grades K-12, 115126. Virginia USA: NCTM

Basir, MA. (2015). Pengembangan Bahan Ajar Trigonometri melalui Model Pembelajaran Search, Solve, Create, and Share untuk Meningkatkan Kemampuan Penalaran. Paper presented at the national seminary on Yogyakarta State University

Blanton, M.L., Kaput, JJ. (2005). Functional Thinking as a Route into Algebrain The Elementary Grades. International reviews on Mathematical Education, 37(1), 34-42

Driscoll, et.al. (2003). The Fostering Algebraic Thinking Toolkit: A Guide for Staff Development. 
National Science Foundation, Arlington, VA

Jones. G.A, Thornton, C.A, Langrall, C.W, dan Tarr, J.E. (1999). Understanding Students' Probabilistic Reasoning. in Lee V. Stiff dan Frances R. Curcio (edt) Developing Mathematical Reasoning in Grades K-12, 146155. Virginia USA: NCTM.

Kemdikbud. (2012). Pengembangan Kurikulum 2013. Jakarta: Kemdikbud

NCTM. (2000). Principle and Standards for School Mathematics: USA.

Russel, Susan Jo. (1999). Mathematical Reasoning in the Elementary Grades. in Lee V. Stiff dan Frances R. Curcio (edt) Developing Mathematical Reasoning in Grades K-12, 1-12. Virginia USA: NCTM.
Thiagarajan, S.D. S. Semmel, dan M. I. Semmel. (1974). Instructional Development for Training Teachers of Exceptional Children, A Source Book. Blomington: Indiana University.

Van de Walle, J..(2007). Matematika Sekolah Dasar dan menengah. Erlangga: Jakarta

Yachel, Erna. (1997). A Foundation of Algebraic Reasoning in The Early Grades. Teaching Children Mathematics 3.

Yeo, J.B.W \& Yeap, B.H. (2009). Solving Mathematical problems by investigation. In B. kaur B.H Yeap \& M. Kapur (Eds.) Mathematical problem solving: Association of Mathematics Educators Yearbook 2009 (pp. 118-136). Singapore: World Scientific. 